\title{
The course of birch pollen seasons in Sosnowiec (Southern Poland) in 1997-2020 in relation to meteorological conditions
}

\author{
Katarzyna Dąbrowska-Zapart (iD) Tadeusz Niedźwiedź $\mathbb{C}$
}

Received: 7 April 2021 / Accepted: 2 December 2021 / Published online: 17 December 2021

(C) The Author(s) 2021

\begin{abstract}
The study's main objective was to specify the extent to which weather conditions were related to the course of birch pollen seasons in the years 1997-2020. The impact of atmospheric conditions on the daily concentrations of birch pollen grains, the Annual pollen integral (APIn), and the length of pollen seasons were studied. The dependency between each meteorological condition and various features of the birch pollen season was determined using Spearman's rho correlation, the Kruskal-Wallis test, and cluster analysis with the k-means method. It has been shown that the duration of sunshine and average air temperature occurring within 14 days preceding the season has the most significant influence on the beginning of a birch pollen season. The value of daily birch pollen concentrations in Sosnowiec showed a statistically significant positive correlation with the duration of sunlight and the average and maximum wind speed. The daily concentration also depended on the synoptic situation: the mass airflow direction, the type of air mass inflow, and the type of weather front. The nearground temperature influenced the APIn of birch
\end{abstract}

Supplementary Information The online version contains supplementary material available at https://doi.org/10.1007/ s10453-021-09734-3.

K. Dąbrowska-Zapart $(\bowtie) \cdot$ T. Niedźwiedź Faculty of Natural Sciences, Institute of Earth Sciences, University of Silesia in Katowice, Będzińska 60,

41-200 Sosnowiec, Poland

e-mail: katarzyna.dabrowska-zapart@us.edu.pl pollen grains during the period of 14 days before the beginning of the season and the meteorological conditions occurring in the summer of the preceding year such as the maximum temperature, duration of sunlight, the maximum and average wind speed, and the relative air humidity. It was concluded that the length of birch pollen seasons decreased year by year.

Keywords Birch pollen - Betula $\cdot$ Weather conditions $\cdot$ Statistical analysis

\section{Introduction}

The Betula tree range is limited to the northern hemisphere, where they mainly occur in the temperate and cold zones. In Poland, the most common are Betula pendula and Betula pubescens (Szweykowska \& Szweykowski, 2003). Birch pollen grains occur in almost all of Europe, from Scandinavia to central Spain and Italy. The highest pollen concentrations of this taxon are recorded in the Boreal regions, in Latvia, Finland, and Poland, among others. Poland was recognized as an area with a high birch pollen concentration (Skjøth et al., 2013). According to Skjøth et al. (2008), the density of Betula sp. in deciduous forests is between 5 and 40 per cent in the lowland areas of the country. The tree pollen release is determined by a few factors, including the time of day, 
biological and meteorological parameters, such as pollination progression, temperature, relative humidity, and wind speed (Nowosad, 2015). Both the beginning and the amount of daily pollen release depend mainly on daily temperatures. If the specified thresholds are not reached, pollination will not start. A similar correlation is observed in many species, which means that slight temperature variation (e.g. $2{ }^{\circ} \mathrm{C}$ ) can have a significant impact on daily pollen release (Dosio \& Paruolo, 2011; Skjøth et al., 2015).

Birch pollen may appear in the air in April and May, and its allergens are one of the most potent allergens among the Polish population (Samoliński et al., 2014). There is a high degree of cross-reactivity within the Betulaceae (e.g. Corylus, Alnus, Betula) family (Ebner et al., 1995). Hazel and alder pollen may cause more severe and more prolonged clinical symptoms in the birch pollen season (D'Amato et al. 2007). Furthermore, the extension of pollen seasons and their subsequent overlapping becomes alarming, as it may cause a higher incidence of cross-reactivity among allergens of the Betulaceae family (Dalen \& Voorhorst, 1981; Eriksson et al., 1987; Mothes \& Valenta, 2004).

Pollen grains constitute a vital problem affecting human health since they cause allergic diseases such as asthma, rhinitis, and allergic conjunctivitis (TraidlHoffmann et al., 2003). The intensification of symptoms is strictly dependent on the degree of exposure to a given allergen and the ambient concentration of the allergen (Lipiec et al., 2005; Rapiejko et al., 2007). Individual plants, however, pollinate with various intensities. The maximum concentration of grass pollen usually does not exceed 300-500 grains $/ \mathrm{m}^{3}$ per day in urban conditions (Rapiejko et al., 2003). In contrast, the birch pollen concentration in the majority of Polish cities usually exceeds 1500 grains $/ \mathrm{m}^{3}$ per day (sometimes reaching even 8000 grains $/ \mathrm{m}^{3}$ ) (Rapiejko et al., 2006).

Usually, the concentration threshold at which allergy symptoms occur depends on the taxon, yet sometimes symptoms of various intensity may arise in the same concentration level (Veriankaite et al., 2010). The correlation between the clinical image of allergic diseases and the level of pollen concentration in Poland was examined by Rapiejko et al. (2007). Their study showed that the first symptoms in the upper respiratory tract in patients allergic to birch pollen were visible during exposure to the pollen at a concentration of 20 grains $/ \mathrm{m}^{3}$ (25\% of participants were allergic to birch pollen). The symptoms were found in all study participants allergic to birch pollen at a concentration higher or equal to 75 grains per $\mathrm{m}^{3}$, and dyspnoea occurred at a concentration of 155 grains $/ \mathrm{m}^{3}$ (Table 1 ).

The main objective of the study was to specify the extent to which weather conditions such as air temperature, duration of sunlight, wind speed, humidity, precipitation, and synoptic situations (the direction of air mass inflow, the type of mass air, and the movement of weather fronts) were related to the course of birch pollen seasons in the years 1997-2020.

\section{Materials and methods}

Birch pollen grain concentrations were analysed based on data obtained in Sosnowiec in the years 1997-2020. Sosnowiec is located in the south of Poland, in the eastern part of the Silesian Upland (Fig. 1). Despite its substantial density of residential and industrial development, the city is a habitat for many species of vascular plants of many botanic families. According to Jędrzejko (1993), green areas make up approximately $24.7 \%$ of the city's territory. The climate conditions of the Silesian Upland are largely varying and irregular. The city is located in a temperate climate zone, transitioning between the maritime and continental zone. During most days of the year $(65 \%)$, the weather is formed under the influence of polar maritime air moving in from the Atlantic Ocean. The average annual temperature is $9.2{ }^{\circ} \mathrm{C}$, with July being the hottest month $\left(19.5^{\circ} \mathrm{C}\right)$, and January the coldest $\left(-1.2^{\circ} \mathrm{C}\right)$. The average annual precipitation is $735 \mathrm{~mm}$. Snowfall is recorded approximately 50 days a year. The average number of days with snow cover is 66 , while the average thickness of the snow cover is $25 \mathrm{~cm}$. The movement of weather fronts over Sosnowiec is accompanied by high weather changeability and precipitation for $40.5 \%$ of days in the year. As far as wind in Sosnowiec is concerned, the western wind is dominant, followed by the southern, north-western, and south-western winds. The average wind speed in Sosnowiec is estimated at approx. $3.1 \mathrm{~m} / \mathrm{s}$ (Niedźwiedź \& Małarzewski, 2016).

Aerobiological measurements were conducted using a volumetric method with a Burkard trap placed on the Institute of Earth Sciences roof at the University 
Table 1 Basic characteristics of birch pollen season during the 1997-2020 time period

\begin{tabular}{|c|c|c|c|c|c|c|c|c|c|}
\hline Year & $\begin{array}{l}\text { Day of } \\
\text { season start }\end{array}$ & $\begin{array}{l}\text { Day of } \\
\text { season end }\end{array}$ & $\begin{array}{l}\text { Length of the } \\
\text { season }\end{array}$ & $\begin{array}{l}\text { Maximum } \\
\text { concentration }\end{array}$ & $\begin{array}{l}\text { Date of max } \\
\text { concentration }\end{array}$ & APIn & $\begin{array}{l}\geq 20 \\
\text { grains } / \mathrm{m}^{3}\end{array}$ & $\begin{array}{c}\geq 75 \\
\text { grains/ } \\
\mathrm{m}^{3}\end{array}$ & $\begin{array}{c}\geq 155 \\
\text { grains/ } \\
\mathrm{m}^{3}\end{array}$ \\
\hline 1997 & $\begin{array}{l}26.03 \\
(85)\end{array}$ & $\begin{array}{l}2.07 \\
(183)\end{array}$ & 99 & 51 & $\begin{array}{l}2.06 \\
(153)\end{array}$ & 205 & 1 & 0 & 0 \\
\hline 1998 & $\begin{array}{l}31.03 \\
(90)\end{array}$ & $\begin{array}{l}7.06 \\
(158)\end{array}$ & 69 & 213 & $\begin{array}{l}11.04 \\
(101)\end{array}$ & 1.513 & 14 & 10 & 2 \\
\hline 1999 & $\begin{array}{l}24.03 \\
(83)\end{array}$ & $\begin{array}{l}15.06 \\
(166)\end{array}$ & 84 & 973 & $\begin{array}{l}8.04 \\
(98)\end{array}$ & 4.874 & 20 & 11 & 8 \\
\hline 2000 & $\begin{array}{l}11.04 \\
(102)\end{array}$ & $\begin{array}{l}18.05 \\
(139)\end{array}$ & 38 & 1835 & $\begin{array}{l}22.04 \\
(113)\end{array}$ & 10.832 & 25 & 15 & 11 \\
\hline 2001 & $\begin{array}{l}4.04 \\
(94)\end{array}$ & $\begin{array}{l}14.06 \\
(165)\end{array}$ & 72 & 2.584 & $\begin{array}{l}2.05 \\
(122)\end{array}$ & 11.327 & 24 & 9 & 9 \\
\hline 2002 & $\begin{array}{l}31.03 \\
(90)\end{array}$ & $\begin{array}{l}21.05 \\
(141)\end{array}$ & 52 & 264 & $\begin{array}{l}19.04 \\
(109)\end{array}$ & 1.908 & 21 & 9 & 3 \\
\hline 2003 & $\begin{array}{l}19.04 \\
(109)\end{array}$ & $\begin{array}{l}13.05 \\
(133)\end{array}$ & 25 & 9.967 & $\begin{array}{l}26.04 \\
(116)\end{array}$ & 28.662 & 22 & 17 & 13 \\
\hline 2004 & $\begin{array}{l}8.04 \\
(99)\end{array}$ & $\begin{array}{l}13.05 \\
(134)\end{array}$ & 36 & 2.203 & $\begin{array}{l}22.04 \\
(113)\end{array}$ & 12.871 & 23 & 18 & 13 \\
\hline 2005 & $\begin{array}{l}29.03 \\
(88)\end{array}$ & $\begin{array}{l}12.06 \\
(163)\end{array}$ & 76 & 508 & $\begin{array}{l}17.04 \\
(107)\end{array}$ & 2.165 & 16 & 5 & 4 \\
\hline 2006 & $\begin{array}{l}16.04 \\
(106)\end{array}$ & $\begin{array}{l}21.05 \\
(141)\end{array}$ & 36 & 6.022 & $\begin{array}{l}23.04 \\
(113)\end{array}$ & 23.025 & 30 & 20 & 13 \\
\hline 2007 & $\begin{array}{l}8.04 \\
(98)\end{array}$ & $\begin{array}{l}11.05 \\
(131)\end{array}$ & 34 & 1.048 & $\begin{array}{l}16.04 \\
(106)\end{array}$ & 4.484 & 23 & 12 & 6 \\
\hline 2008 & $\begin{array}{l}7.04 \\
(98)\end{array}$ & $\begin{array}{l}18.05 \\
(139)\end{array}$ & 42 & 3.760 & $\begin{array}{l}16.04 \\
(107)\end{array}$ & 24.456 & 37 & 25 & 21 \\
\hline 2009 & $\begin{array}{l}7.04 \\
(97)\end{array}$ & $\begin{array}{l}18.05 \\
(138)\end{array}$ & 42 & 150 & $\begin{array}{l}19.04 \\
(109)\end{array}$ & 1.314 & 19 & 6 & 0 \\
\hline 2010 & $\begin{array}{l}4.04 \\
(94)\end{array}$ & $\begin{array}{l}13.05 \\
(133)\end{array}$ & 40 & 1.561 & $\begin{array}{l}19.04 \\
(109)\end{array}$ & 10.926 & 25 & 20 & 17 \\
\hline 2011 & $\begin{array}{l}6.04 \\
(96)\end{array}$ & $\begin{array}{l}13.05 \\
(133)\end{array}$ & 38 & 290 & $\begin{array}{l}19.04 \\
(109)\end{array}$ & 2.100 & 20 & 10 & 3 \\
\hline 2012 & $\begin{array}{l}10.04 \\
(101)\end{array}$ & $\begin{array}{l}14.05 \\
(135)\end{array}$ & 35 & 5.795 & $\begin{array}{l}20.04 \\
(111)\end{array}$ & 17.674 & 26 & 20 & 14 \\
\hline 2013 & $\begin{array}{l}21.04 \\
(111)\end{array}$ & $\begin{array}{l}11.05 \\
(131)\end{array}$ & 21 & 892 & $\begin{array}{l}24.04 \\
(114)\end{array}$ & 4058 & 10 & 8 & 5 \\
\hline 2014 & $\begin{array}{l}30.03 \\
(89)\end{array}$ & $\begin{array}{l}5.05 \\
(125)\end{array}$ & 37 & 1.859 & $\begin{array}{l}8.04 \\
(98)\end{array}$ & 11.054 & 28 & 19 & 16 \\
\hline 2015 & $\begin{array}{l}11.04 \\
(101)\end{array}$ & $\begin{array}{l}12.05 \\
(132)\end{array}$ & 32 & 476 & $\begin{array}{l}23.04 \\
(113)\end{array}$ & 2.515 & 16 & 11 & 6 \\
\hline 2016 & $\begin{array}{l}3.04 \\
(94)\end{array}$ & $\begin{array}{l}17.05 \\
(138)\end{array}$ & 45 & 2.993 & $\begin{array}{l}13.04 \\
(104)\end{array}$ & 19.087 & 39 & 28 & 21 \\
\hline 2017 & $\begin{array}{l}31.03 \\
(90)\end{array}$ & $\begin{array}{l}24.05 \\
(144)\end{array}$ & 55 & 1.070 & $\begin{array}{l}5.04 \\
(95)\end{array}$ & 4.112 & 25 & 12 & 6 \\
\hline
\end{tabular}


Table 1 continued

\begin{tabular}{|c|c|c|c|c|c|c|c|c|c|}
\hline Year & $\begin{array}{l}\text { Day of } \\
\text { season start }\end{array}$ & $\begin{array}{l}\text { Day of } \\
\text { season end }\end{array}$ & $\begin{array}{l}\text { Length of the } \\
\text { season }\end{array}$ & $\begin{array}{l}\text { Maximum } \\
\text { concentration }\end{array}$ & $\begin{array}{l}\text { Date of max } \\
\text { concentration }\end{array}$ & APIn & $\begin{array}{l}\geq 20 \\
\text { grains } / \mathrm{m}^{3}\end{array}$ & $\begin{array}{c}\geq 75 \\
\text { grains/ } \\
\mathrm{m}^{3}\end{array}$ & $\begin{array}{c}\geq 155 \\
\text { grains/ } \\
\mathrm{m}^{3}\end{array}$ \\
\hline 2018 & $\begin{array}{l}9.04 \\
(99)\end{array}$ & $\begin{array}{l}14.05 \\
(134)\end{array}$ & 36 & 2.658 & $\begin{array}{l}12.04 \\
(102)\end{array}$ & 9.112 & 19 & 12 & 10 \\
\hline 2019 & $\begin{array}{l}4.04 \\
(94)\end{array}$ & $\begin{array}{l}9.05 \\
(129)\end{array}$ & 36 & 1.894 & $\begin{array}{l}19.04 \\
(109)\end{array}$ & 10.420 & 23 & 20 & 15 \\
\hline 2020 & $\begin{array}{l}6.04 \\
(97)\end{array}$ & $\begin{array}{l}13.05 \\
(134)\end{array}$ & 38 & 1.732 & $\begin{array}{l}13.04 \\
(104)\end{array}$ & 5.243 & 25 & 16 & 8 \\
\hline
\end{tabular}

of Silesia in Katowice, in the Northern Pogon district of Sosnowiec, where there is a low-density residential development. The trap is placed approx. $15 \mathrm{~m}$ above the ground. The geographical coordinates of the measurement point are as follows: $50^{\circ} 17^{\prime} 50^{\prime \prime} \mathrm{N}$ and $19^{\circ} 08^{\prime} 20^{\prime \prime}$. Nearby, at the height of $263 \mathrm{~m}$ above sea level, there is a weather station of the Institute of Earth Sciences, which was the source of weather data. Additional data came from a synoptic weather station of the Institute of Meteorology and Water Management in Katowice, which is located approx. $10 \mathrm{~km}$ southwest of Sosnowiec. From the station located in Katowice, sunshine data from 1997 to 2000, humidity data for all years, and precipitation data from 1997 to 2001 and 2010-2020 were obtained.

The study used average daily and monthly values of weather elements such as average, near-ground, maximum and minimum air temperature, duration of sunlight, relative humidity, average and maximum wind speed, precipitation, and the type of atmospheric circulation (Niedźwiedź, 1981, 2004, 2006).

The microscopic samples were taken from the palynological material obtained by measurements with the Burkard trap, and after staining them with alkaline fuchsine-evaluated on the surface of 4 horizontal strips (Mandrioli et al., 1998) with the help of a microscope with trans-illumination.

The duration of the pollen season was determined using the $98 \%$ method. It is assumed that it started and ended on the days with $1 \%$ and $99 \%$ of APIn, respectively (Emberlin et al., 1994; Spieksma and Nikkels 1998). The following seasonal properties were identified: its start date and end date, its duration, the Annual pollen integral (APIn), the maximum daily concentration, the date of the highest concentration, and the number of days when the concentration exceeded the threshold values (20-155 grains $/ \mathrm{m}^{3}$ ). The threshold values were defined based on the airborne birch pollen concentration, which has caused allergy symptoms in Poland (Rapiejko et al., 2007). The dates related to the beginning, end, and peak of pollen seasons were converted into the day of the year, counting from 1 January. Descriptive statistics were used for the analysis of differences in the course of pollen seasons in the years examined: the arithmetic mean, the minimum and maximum pollen concentration, standard deviation, and the coefficient of variation. The following interpretation was applied to assess the coefficient of variation $(\mathrm{V}): \mathrm{V}<20 \%$-low variation, $20 \%<\mathrm{V}<40 \%$-average variation, $40 \%<\mathrm{V}<100 \%$-high variation, $>100 \%$-very strong variation. To check whether the distribution of variables is similar to the norm, the KolmogorovSmirnov and Shapiro-Wilk tests were conducted (level 0.05; data not shown). Because the birch pollen distribution in these years was strongly skewed (this includes both daily and seasonal data), and there was high variation in results (the ratio of standard deviation to the mean), appropriate nonparametric tests were used to verify the correlation between the measurements: Spearman's rho correlation analysis and the Kruskal-Wallis test. The correlation strength was measured using the following ranges: $0-0.3$ poor correlation, $0.3-0.5$ moderate correlation, $0.5-0.7$ strong correlation, $0.7-1$ very strong correlation. In order to verify whether there are similar pollen seasons in terms of the pollen grain concentration and the season's duration, grouping was performed using cluster analysis. A non-hierarchical method of multifeature object grouping was applied-the k-means 


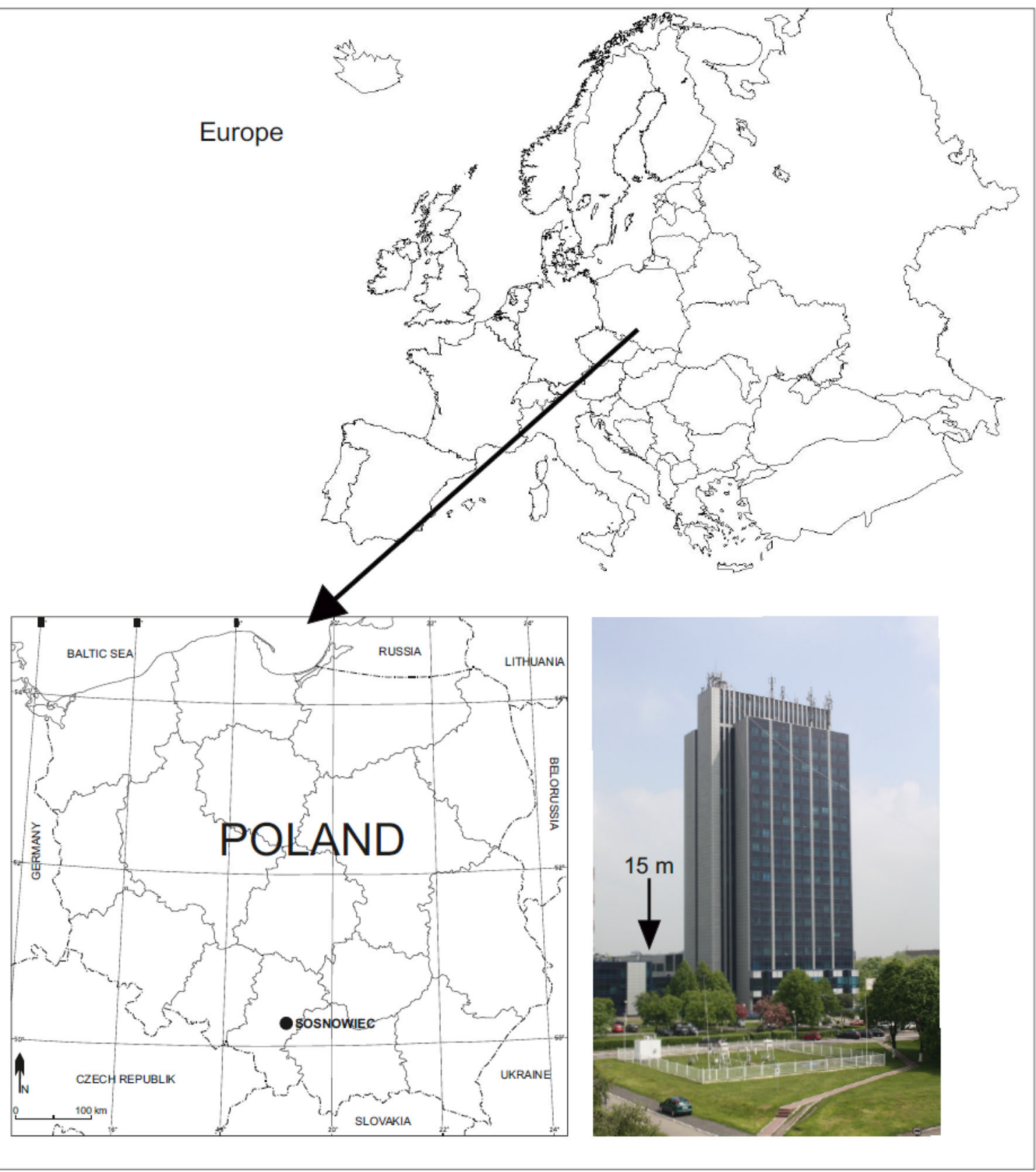

Fig. 1 The geographic location of Sosnowiec in central Europe and location of the measuring point at the Institute of Earth Sciences, University of Silesia, Sosnowiec

method. However, first (before the k-means method), a hierarchical cluster analysis using Ward's method was performed to see the most reliable number of clusters. Daily, monthly and annual data on birch pollen grain concentration and meteorological conditions were used in the statistical analyses. For daily concentrations, daily data were considered, for the effect of weather conditions in the year preceding pollination, monthly data were analysed, and for APIn, annual data were examined. The periods of 4, 14, and 28 days before the start of pollen season were used for analyses of the effects of weather conditions on the start of the birch pollen season. 


\section{Results}

A 24-year series of aerobiological data on the course of birch pollen seasons were analysed. Particular characteristics of pollen seasons are included in Table 1. The most unusual season turned out to be that of 1997. It was characterized by low concentrations and was exceptionally long (Table 1). As regards the threshold values at which allergic symptoms occur-the highest number of such days was observed in 2008 and 2016.

The maximum daily values and APIn were of the highest variability among the characteristics of birch pollen seasons studied. The most significant coefficient of skewness, right-handed in both cases, was found for maximum daily concentration and the date of maximum concentration (Table 2).

3.1 The influence of weather conditions on the daily concentration of birch pollen

To examine the correlation of the daily concentration of birch pollen grains with weather conditions, a series of Spearman's rho correlation analyses was conducted, the results of which are presented in the table below (Table 3). Use of the series of Spearman's rho correlation analysis indicated that the birch pollen concentration had a statistically significant correlation with the minimum air temperature $r s=-0.17$; $p<0.001$ and near-ground temperature $r s=-0.18$; $p<0.001$.
It was also demonstrated that the daily birch pollen grain concentration was statistically significantly correlated with the duration of sunlight $r s=0.12$; $p<0.001$, average wind speed $r s=0.15 ; p<0.001$ and the maximum wind speed $r s=0.20 ; p<0.001$. Negative correlations were found for relative air humidity $r s=-0.29 ; p<0.001$, and precipitation $r s=-0.15 ; p<0.001$ (Table 3).

Next, it was examined whether and how air circulation had an influence on the amount of birch pollen grains.

Table 4 presents the percentage share of weather fronts occurring during the birch pollen season and descriptive statistics for the pollen concentration during the movement of the fronts. Due to a strongly skewed distribution of birch pollen concentrationthe analyses of the average and standard deviation were supplemented by the median and range values set by the first and third quartile.

The analysis conducted using the Kruskal-Wallis test showed that the front type had a statistically significant $(p<0.01)$ influence on the birch pollen concentration during the pollen season. During birch pollination, there most often was no front, then a cold front, more rarely a warm or stationary one. The highest birch pollen concentration was recorded in the case of a stationary front and in the case of no front, and the lowest—during the occluded front (based on the median value) (Fig. 2).

Table 2 Statistics of the birch pollen season in Sosnowiec

\begin{tabular}{|c|c|c|c|c|c|c|c|c|c|}
\hline \multicolumn{10}{|c|}{ Data from the years $1997-2020$} \\
\hline & $\begin{array}{l}\text { Day of } \\
\text { the season } \\
\text { start }\end{array}$ & $\begin{array}{l}\text { Day of } \\
\text { the season } \\
\text { end }\end{array}$ & $\begin{array}{l}\text { Length } \\
\text { of the } \\
\text { season }\end{array}$ & $\begin{array}{l}\text { Maximum } \\
\text { concentration }\end{array}$ & $\begin{array}{l}\text { Date of } \\
\text { max } \\
\text { concentration }\end{array}$ & APIn & $\begin{array}{l}\geq 20 \\
\text { grains } / \mathrm{m}^{3}\end{array}$ & $\begin{array}{l}\geq 75 \\
\text { grains } / \mathrm{m}^{3}\end{array}$ & $\begin{array}{l}\geq 155 \\
\text { grains } / \mathrm{m}^{3}\end{array}$ \\
\hline $\bar{X}$ & 96 & 142 & 47 & 2.117 & 110 & 9.508 & 22.0 & 13.8 & 9.4 \\
\hline Min & 83 (1999) & 125 (2014) & $21(2013)$ & $51(2002)$ & 95 (2017) & 205 (1997) & 1 (1997) & 0 (1997) & 0 (1997) \\
\hline Max & $111(2013)$ & 183 (1997) & 99 (1997) & $9.967(2003)$ & 153 (1997) & $28.662(2003)$ & 39 (2016) & $28(2016)$ & $21(2016)$ \\
\hline $\mathrm{SD}$ & 7.02 & 14.5 & 19.5 & 2.320 .9 & 11.1 & 8.234 .7 & 8.0 & 6.7 & 6.3 \\
\hline $\mathrm{V}(\%)$ & 7.31 & 10.2 & 41.8 & 109.6 & 10.1 & 86.6 & 36.4 & 48.9 & 66.7 \\
\hline Sk & 0.3 & 1.5 & 1.3 & 2.1 & 2.6 & 1.0 & -0.3 & 0.1 & 0.3 \\
\hline
\end{tabular}

$\bar{x}$, Arithmetic mean; Min, Minimal concentration of pollen grains; Max, Maximum concentration of pollen grains; SD, Standard deviation; V, Coefficient of variation; Sk, Skewness. 
Table 3 Results of Spearman's rho correlation analysis relating the daily pollen count of birch and meteorological conditions

$* * p<0.01 ; * * * p<0.001$

\begin{tabular}{lc}
\hline Weather conditions & Spearman's rho with daily pollen concentration \\
\hline Maximum temperature & 0.03 \\
Minimum temperature & $\mathbf{- 0 . 1 7 * * *}$ \\
Temperature $5 \mathrm{~cm}$ near the ground & $\mathbf{- 0 . 1 8 * * *}$ \\
Average temperature & -0.03 \\
Sunlight duration & $\mathbf{0 . 1 2} * * *$ \\
Average wind speed & $\mathbf{0 . 1 5} * * *$ \\
Maximum wind speed & $\mathbf{0 . 2 0} * * *$ \\
Relative humidity & $\mathbf{- 0 . 2 9 * * *}$ \\
Precipitation & $\mathbf{- 0 . 1 5 * * *}$ \\
\hline
\end{tabular}

Table 4 Results of comparative analysis by Kruskal-Wallis test regarding the daily pollen concentration of birch and the type of atmospheric front

\begin{tabular}{lcccc}
\hline Front type & Frequency $\%$ & $M$ & $S D$ & $M e(Q 1-Q 3)$ \\
\hline No front & $61.00 \%$ & 182.26 & 456.26 & $19.5(3-121)$ \\
Warm & $8.41 \%$ & 344.01 & 1228.10 & $15.5(3-81)$ \\
Cold & $15.47 \%$ & 175.40 & 543.06 & $10(2-96)$ \\
Occluded & $3.31 \%$ & 198.67 & 124.12 & $3(1-41)$ \\
Stationary & $7.78 \%$ & 396.91 & 421.37 & $23(4.5-110.5)$ \\
Various fronts & $4.03 \%$ & $p<0.01$ & 1059.87 & $12(2-49)$ \\
$p$ & & &
\end{tabular}

$M$, Average; $S D$, Standard deviation; $Q 1$, First quartile; $M e$, Median; $Q 3$, Third quartile

Another analysis by the Kruskal-Wallis test examined the influence of the air mass on the birch pollen concentration (Table 5).
Using the Kruskal-Wallis test, demonstrated that the birch pollen concentration had a statistically significant variation due to the direction of the mass air inflow $p<0.001$ (Table 5). Based on the median
Fig. 2 Median of the daily pollen concentration of birch by type of atmospheric front

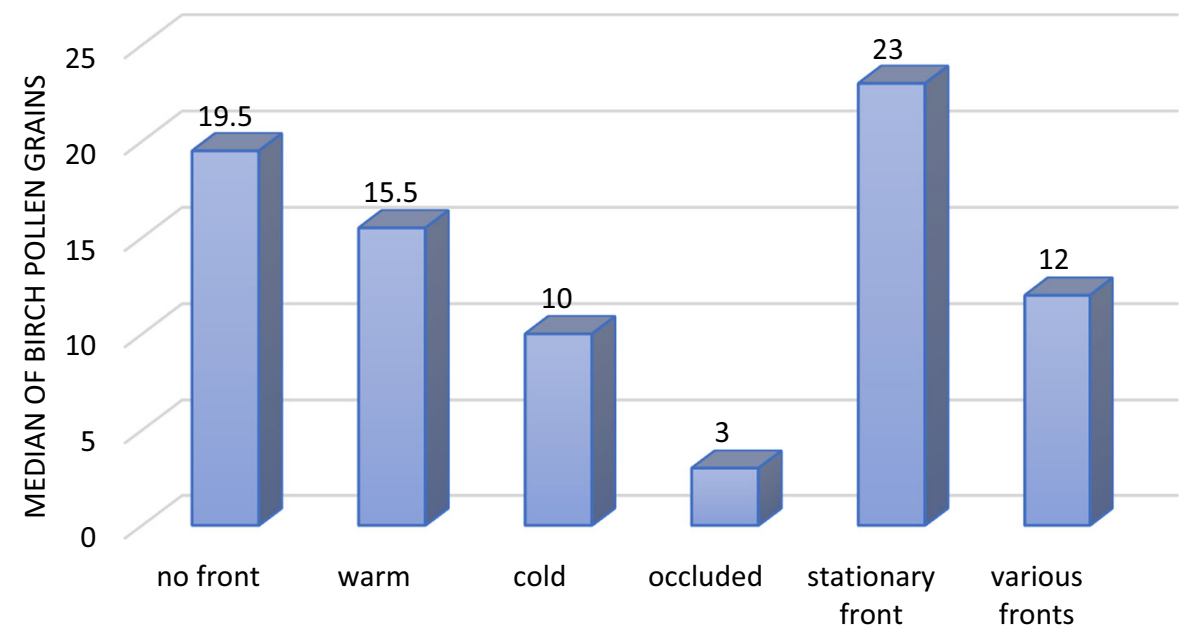

Front type 
Table 5 Results of the comparative analysis by KruskalWallis test for the daily pollen count of birch concerning the air mass direction

\begin{tabular}{lcccl}
\hline Direction & Frequency $\%$ & $M$ & \multicolumn{1}{l}{$S D$} & $M e(Q 1-Q 3)$ \\
\hline $\mathrm{N}+\mathrm{NEa}$ & $9.21 \%$ & 154.84 & 578.69 & $15(3-88.5)$ \\
$\mathrm{E}+\mathrm{SEa}$ & $9.93 \%$ & 169.97 & 317.91 & $36(6.5-141)$ \\
$\mathrm{S}+\mathrm{SWa}$ & $6.08 \%$ & 222.09 & 422.82 & $18.5(3-226)$ \\
$\mathrm{W}+\mathrm{NWa}$ & $6.26 \%$ & 159.31 & 322.37 & $14(2-124)$ \\
$\mathrm{Ca}+\mathrm{Ka}$ & $14.40 \%$ & 147.54 & 350.77 & $13(1-84)$ \\
$\mathrm{N}+\mathrm{NEc}$ & $7.60 \%$ & 160.29 & 485.71 & $10(1-108)$ \\
$\mathrm{E}+\mathrm{SEc}$ & $7.07 \%$ & 259.22 & 587.59 & $43(8-177)$ \\
$\mathrm{S}+\mathrm{SWc}$ & $10.29 \%$ & 287.61 & 1048.19 & $24(6.5-92.5)$ \\
$\mathrm{W}+\mathrm{NWc}$ & $9.93 \%$ & 159.41 & 455.27 & $11(3-51.5)$ \\
$\mathrm{Cc}+\mathrm{Bc}$ & $16.37 \%$ & 270.97 & 790.96 & $12(2-81)$ \\
$\mathrm{x}$ & $2.86 \%$ & 145.44 & 465.04 & $15(2-69.5)$ \\
$p$ & \multicolumn{5}{c}{0.001} & & \\
\hline
\end{tabular}

$M$, Average; $S D$, Standard deviation, $Q 1$, First quartile, $M e$, Median, Q3, Third quartile

Anti-cyclonic situations: $\mathrm{N}+\mathrm{NEa}, \mathrm{E}+\mathrm{SEa}, \mathrm{S}+\mathrm{Swa}$, $\mathrm{W}+\mathrm{NWa}, \mathrm{Ca}+\mathrm{Ka}, \mathrm{Ca}-$ central anticyclone situation (high centre), $\mathrm{Ka}$-anti-cyclonic wedge or ridge of high pressure

Cyclonic situations: $\mathrm{N}+\mathrm{NEc}, \mathrm{E}+\mathrm{SEc}, \mathrm{S}+\mathrm{SWc}$, $\mathrm{W}+\mathrm{NWc}, \mathrm{Cc}+\mathrm{Bc}, \mathrm{Cc}-$ central cyclonic, centre of low, $\mathrm{Bc}$ - the trough of low pressure (different directions of airflow and frontal system in the trough axis)

$\mathrm{x}$ undefined type

The letters: N, NE, E, SE, S, W, NW, SW indicate the directions of mass air inflow.

value and the interquartile range can conclude that the highest concentration of birch pollen was recorded in the case of mass air inflow from E + SEc (eastern and south-eastern cyclonic flow) and E + SEa (eastern and south-eastern anti-cyclonic flow). The lowest birch pollen concentration was recorded in the case of air inflow from $\mathrm{N}+\mathrm{NEc}$ (northern and north-eastern cyclonic flow), $\mathrm{N}+\mathrm{NEa}$ (northern and north-eastern anti-cyclonic flow), and $\mathrm{W}+\mathrm{NWa}$ (western and north-western anti-cyclonic flow). Low concentrations also occurred when there was a central anti-cyclonic situation (high-pressure centre) and anti-cyclonic ridge or high-pressure ridge $(\mathrm{Ca}+\mathrm{Ka})$, as well as central cyclonic situation (low-pressure centre) or low-pressure furrow ( $\mathrm{Cc}+\mathrm{Bc}$ ) (Fig. 3), that is, on days when the mass air inflow from further areas was weakened.
Similarly, using the Kruskal-Wallis test, the influence of the air mass type on the birch pollen grains during the pollen season was tested (Table 6).

The Kruskal-Wallis test result for comparing of the birch pollen concentration in terms of air mass type was statistically significant $p<0.001$. Based on the median value and interquartile range, it can be determined that the highest birch pollen concentration was recorded in the case of an exceptionally warm air mass $\mathrm{T}$ and $\mathrm{wmP}$ and the lowest in the case of a cool air mass fmP and A (Fig. 4).

\subsection{Variability in birch pollen concentration and variation in atmospheric conditions during pollen season across years}

With the help of the series of Spearman's rho correlation analyses showed that the birch pollen grain concentration was increasing year by year over the analysed period of time $r s=0.42 ; p<0.001$, and the increase was moderately substantial (Table 7).

It was also determined that within the analysed periods of birch pollination, the minimum air temperature $r s=-0.14 ; p<0.001$, the near-ground temperature $r s=-0.11 ; p<0.001$ and average temperature $r s=-0.10 ; p<0.01$ were decreasing, but these correlations were not strong.

Spearman's rho correlation analyses also showed that during birch pollen seasons, the average wind speed $r s=0.17 ; p<0.001$ and maximum wind speed $r s=0.28 ; p<0.001$ were increasing yearly, but the average relative humidity was decreasing $r s=$ $-0.14 ; p<0.001$.

3.3 The effect of weather conditions on APIn and length of birch pollen seasons

The analysis conducted confirmed the earlier results obtained for all measurements. The duration of the birch pollen season was decreasing yearly $r s=$ $-0.44 ; p<0.05$, while the APIn slightly increased (Table 8, Figs. 5, 6).

The correlation between the APIn and the duration of the pollen season and weather conditions in a given year was also examined (Table 9).

The Spearman's rho correlation analysis showed that the APIn was not correlated with weather conditions. It was shown, however, that long pollen seasons occurred in the years of low average $r s=$ 
Fig. 3 Median of the daily pollen concentration of birch by the direction of inflow of the atmospheric front

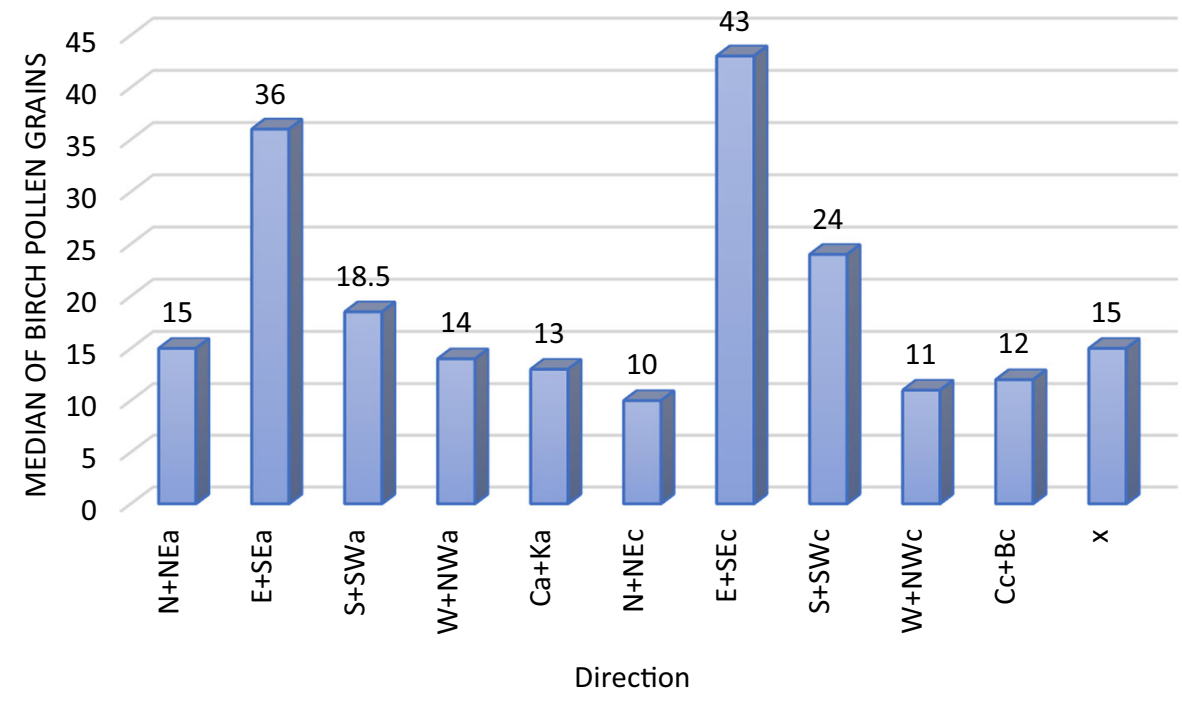

Table 6 Results of a comparative analysis conducted using the Kruskal-Wallis test for the daily birch pollen concentration in terms of air mass type

\begin{tabular}{llccl}
\hline Air mass type & Frequency $(\%)$ & $M$ & $S D$ & $M e(Q 1-Q 3)$ \\
\hline A & 10.20 & 62.07 & 113.89 & $11.5(2-65)$ \\
fmP & 12.70 & 116.94 & 340.78 & $6(1-61)$ \\
omP & 31.93 & 232.74 & 701.65 & $16(2-102)$ \\
cP & 21.11 & 185.78 & 377.40 & $26.5(4-150.5)$ \\
wmP & 10.73 & 299.38 & 636.11 & $25(6-162.5)$ \\
T & 3.85 & 164.04 & 325.91 & $30(5.5-119.5)$ \\
v.a.m & 9.48 & 286.28 & 1060.43 & $16(3-81)$ \\
$p$ & & $p<0.001$ & & \\
\hline
\end{tabular}

$M$, Average; SD, Standard deviation; $Q 1$, First quartile; $M e$, Median; $Q 3$, Third quartile

omP, Old maritime polar air (transformed)

wmP, Warm maritime polar air

fmP, Fresh maritime polar air

$\mathrm{cP}$, Continental polar air

A, Arctic air

T, Tropical air

v.a.m., Various air masses on days with atmospheric fronts

$-0.51 ; p<0.05$ and maximum wind speed $r s=$ $-0.51 ; p<0.05$ and in the years of high average relative air humidity $r s=0.52 ; p<0.05$.

The influence of weather conditions from the year preceding the pollen season on the APIn was also analysed (Table 10). The conducted series of Spearman's rho correlation analyses have demonstrated that the APIn of birch pollen concentration was mostly influenced by the relative humidity from the period of
July-September in the year preceding pollination $r s=0.68 ; p<0.01$. Statistically significant factors were also observed for the maximum temperature $r s=0.55 ; p<0.05$, duration of sunlight $r s=0.48$; $p<0.05$ and the average $r s=-0.63 ; p<0.05$ and maximum wind speed $r s=-0.49 ; p<0.05$ from the period of July-September of the preceding year. 
Fig. 4 Median of the daily pollen concentration of birch by air mass

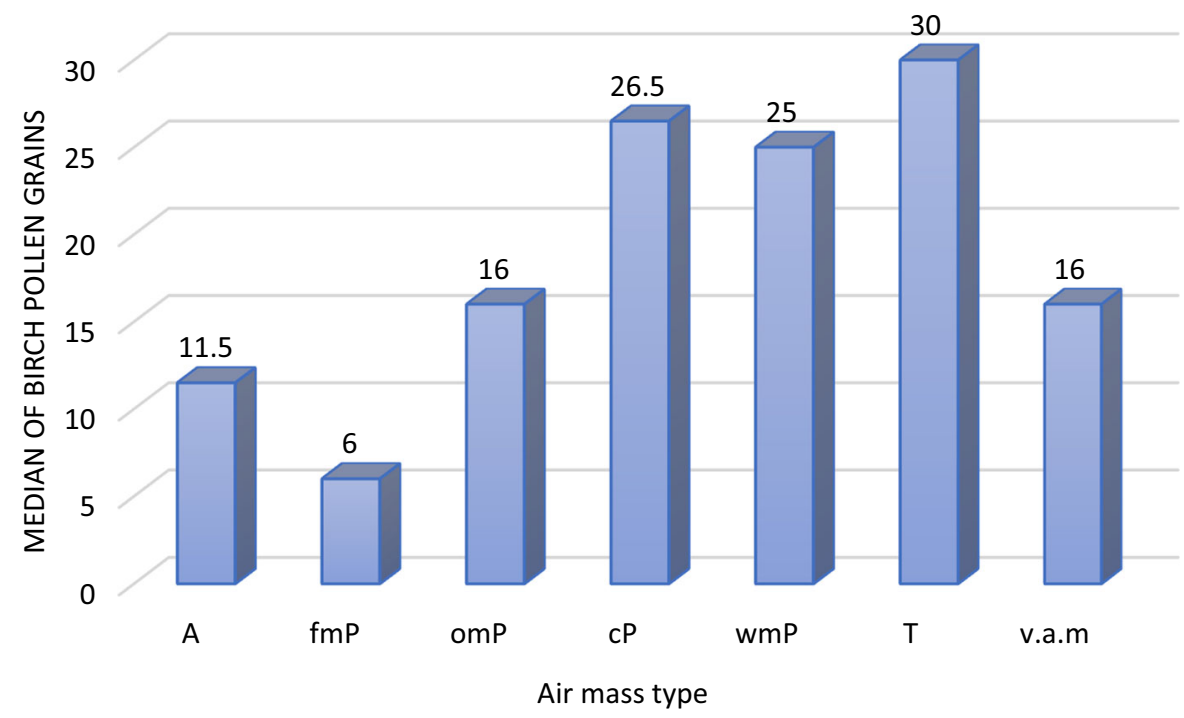

Table 7 Results of Spearman's rho correlation analysis for changes in the daily pollen concentration of birch and meteorological conditions from 1997 to 2020

\begin{tabular}{lc}
\hline & Spearman's rho coefficient \\
\hline Daily pollen concentration & $\mathbf{0 . 4 2} * * *$ \\
Maximum temperature & -0.05 \\
Minimum temperature & $-\mathbf{0 . 1 4} * *$ \\
Ground temperature & $-\mathbf{0 . 1 1} * *$ \\
Average temperature & $-\mathbf{0 . 1 0} * *$ \\
Sunlight duration & -0.01 \\
Average wind speed & $\mathbf{0 . 1 7} * * *$ \\
Maximum wind speed & $\mathbf{0 . 2 8} * *$ \\
Relative humidity & $-\mathbf{0 . 1 4} * *$ \\
Precipitation & -0.05
\end{tabular}

$* p<0.05 ; * * p<0.01 ; * * * p<0.001$

3.4 The effects of pre-season weather conditions on different characteristics of birch pollen seasons

Another series of analyses was conducted to examine to what extent the weather conditions occurring 4,14 , and 28 days before the beginning of the birch pollen season influenced the beginning of this season, the APIn, and the length of the pollen season. The table below presents the results of the Spearman's rho correlation analyses for the variables (Table 11). Spearman's rho correlation analysis showed that
Table 8 Results of Spearman's rho correlation analysis regarding the change in the APIn of birch and duration of the pollen season and meteorological conditions for mean results from 1997 to 2020

\begin{tabular}{lc}
\hline & Spearman's rho coefficient \\
\hline APIn & 0.28 \\
Duration of the pollen season & $-\mathbf{0 . 4 4} *$ \\
Maximum temperature & -0.23 \\
Minimum temperature & $-\mathbf{0 . 4 3} *$ \\
Ground temperature & -0.38 \\
Average temperature & $-\mathbf{0 . 4 1} *$ \\
Sunlight duration & -0.06 \\
Average wind speed & $\mathbf{0 . 4 0}$ \\
Maximum wind speed & $\mathbf{0 . 9 0} * * *$ \\
Relative humidity & -0.23 \\
Precipitation & 0.02 \\
\hline$* p<0.05 ; * *<<0.01 ; * * *<0.001$
\end{tabular}

weather conditions occurring two weeks before the start of the pollen season have the most significant effect on the date of the beginning of the birch pollen season, APIn, and season length. The pollen season started faster when the average temperature and sunlight duration were high $(r s=-0.41 ; p<0.05$ and $r s=-0.44 ; p<0.05)$. This pollen season characteristic was negatively influenced by the average wind speed $r s=0.42 ; p<0.05$, maximum wind speed $r s=0.40 ; p<0.05$ and precipitation $r s=0.50$; $p<0.05$. It has also been that the APIn of birch 
Fig. 5 Variability in APIn of birch pollen from 1997 to 2020

Fig. 6 Variability in the length of birch pollen seasons from 1997 to 2020

Table 9 Results of Spearman's rho correlation analysis examining the correlation between the birch pollen grain concentration and the duration of a pollen season and weather conditions

$* p<0.05$
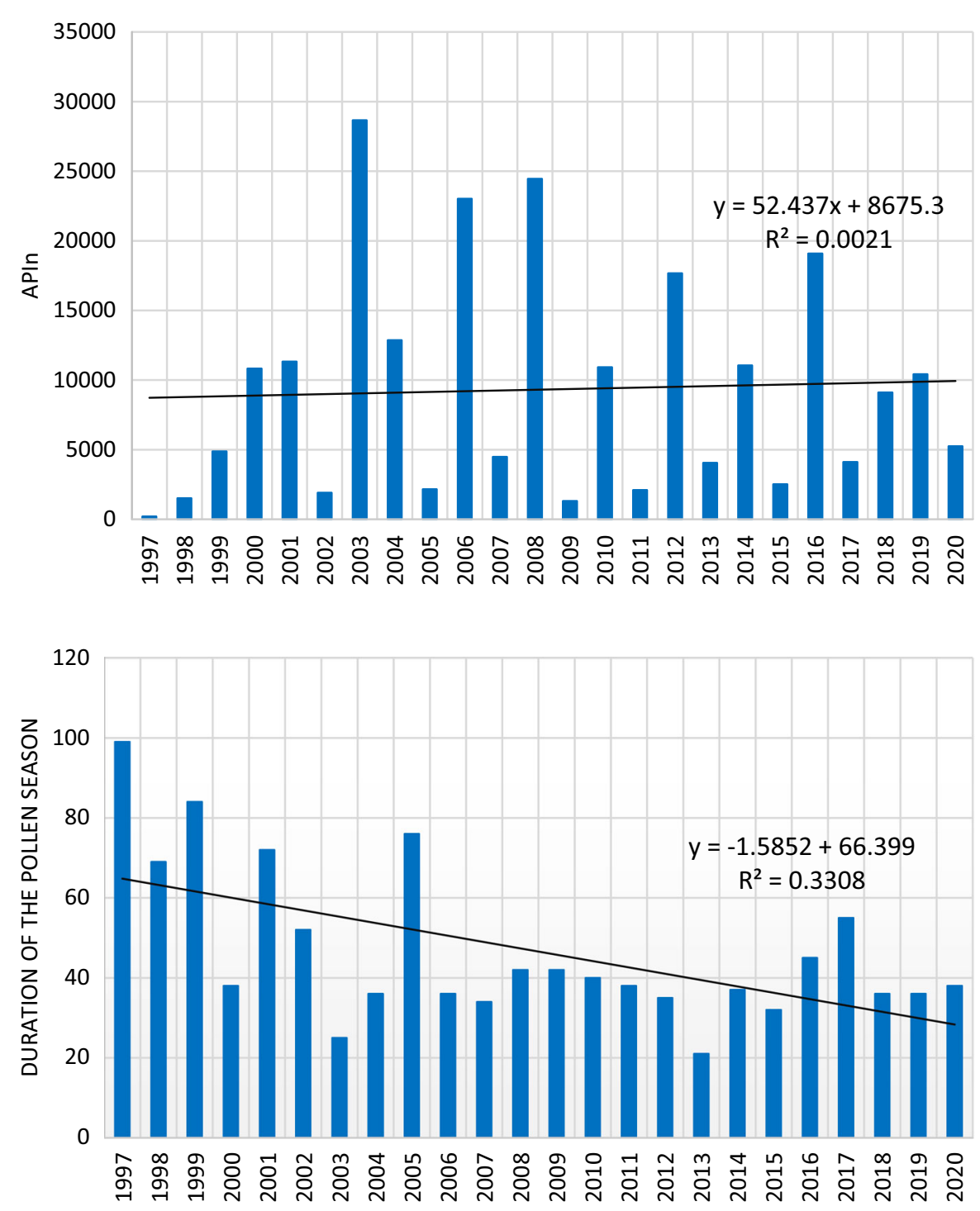

\begin{tabular}{lcl}
\hline Weather conditions & APIn & Length of the season \\
\hline Maximum temperature & 0.04 & -0.36 \\
Minimum temperature & 0.04 & -0.11 \\
Temperature 5 cm near the ground & 0.21 & -0.18 \\
Average temperature & -0.01 & -0.24 \\
Sunlight duration & -0.01 & -0.26 \\
Average wind speed & 0.06 & $-\mathbf{0 . 5 1}^{*}$ \\
Maximum wind speed & 0.32 & $-\mathbf{0 . 5 1}^{*}$ \\
Relative humidity & -0.08 & $\mathbf{0 . 5 2}$ \\
Precipitation & 0.06 & 0.10 \\
\hline
\end{tabular}


Table 10 Results of Spearman's rho correlation analysis regarding meteorological elements in the year preceding pollination and the APIn of birch

\begin{tabular}{lc}
\hline Weather conditions & APIn \\
\hline Maximum temperature July-September & $\mathbf{0 . 5 5 *}$ \\
Minimum temperature July-September & 0.33 \\
Temperature 5 cm near the ground July-September & 0.21 \\
Average temperature July-September & 0.13 \\
Sunlight duration July-September & $\mathbf{0 . 4 8 *}$ \\
Average wind speed July-September & $-\mathbf{0 . 6 3 * *}$ \\
Maximum wind speed July-September & $-\mathbf{0 . 4 9 *}$ \\
Relative humidity July-September & $\mathbf{0 . 6 8 * *}$ \\
Precipitation July-September & 0.49 \\
\hline
\end{tabular}

$* p<0.05 ; * * p<0.01$

Table 11 Results of the Spearman's rho correlation analysis regarding the influence of weather conditions occurring 4 , 14 and 28 days before the beginning of the season on the beginning and length of the pollen season and the APIn

\begin{tabular}{|c|c|c|c|c|c|c|c|c|c|}
\hline \multirow[t]{2}{*}{ Weather conditions } & \multicolumn{3}{|c|}{ Start of the season } & \multicolumn{3}{|l|}{ APIn } & \multicolumn{3}{|c|}{ Length of the season } \\
\hline & 28 & 14 & 4 & 28 & 14 & 4 & 28 & 14 & 4 \\
\hline Maximum temperature & -0.21 & -0.26 & -0.23 & 0.30 & 0.22 & 0.33 & $-0.41^{*}$ & $-0.44 *$ & -0.32 \\
\hline Minimum temperature & -0.11 & -0.35 & -0.13 & 0.25 & 0.32 & 0.20 & -0.20 & -0.40 & -0.21 \\
\hline Ground temperature & -0.23 & -0.37 & -0.21 & 0.13 & $0.42 *$ & 0.13 & -0.09 & $-0.43 *$ & -0.13 \\
\hline Average temperature & -0.30 & $-0.41 *$ & -0.10 & -0.23 & 0.27 & 0.14 & -0.31 & $-0.46^{*}$ & -0.18 \\
\hline Sunshine duration & $-0.40 *$ & $-0.44 *$ & -0.16 & -0.34 & -0.04 & -0.24 & -0.25 & $-0.42 *$ & -0.21 \\
\hline Average wind speed & 0.25 & $0.42 *$ & $0.41 *$ & 0.25 & 0.34 & 0.22 & -0.13 & $-0.45 *$ & -0.19 \\
\hline Maximum wind speed & 0.28 & $0.40 *$ & 0.23 & 0.13 & 0.39 & 0.17 & -0.23 & $-0.50 *$ & -0.16 \\
\hline Relative humidity & -0.11 & 0.22 & 0.19 & 0.16 & $-0 . .16$ & 0.30 & -0.34 & $0.47 *$ & 0.35 \\
\hline Precipitation & 0.20 & $0.50 *$ & -0.13 & 0.22 & 0.27 & 0.23 & 0.25 & -0.12 & 0.14 \\
\hline
\end{tabular}

$* p<0.05$

pollen grains was correlated with a higher near-ground temperature $r s=0.42 ; p<0.05$ occurring two weeks before the pollen season.

Spearman's rho correlation analyses showed that the duration of the birch pollen season was higher when there was a lower maximum temperature $r s=-0.44 ; p<0.05$, near-ground temperature $r s=$ $-0.43 ; p<0.05$, and lower average temperature $r s=-0.46 ; p<0.05$ within 2 weeks before the pollination. Longer pollen seasons were also correlated with a shorter duration of sunlight $r s=-0.42$; $p<0.05$, lower average wind speed $r s=-0.45$; $p<0.05$ and maximum wind speed over the 14 days before the season's beginning. High relative air humidity within two weeks before the season start resulted in the extension of the birch pollination period $r s=0.47 ; p<0.05$.
It was also verified whether and to what extent the birch pollen grain concentration and duration of sunlight were affected by the direction of air mass inflow and the type of the air mass. Because for almost all measurements taken two weeks before pollination there was no front, this variable was not subject to analysis. The comparisons were conducted using the Kruskal-Wallis tests (Table 12).

At the edge of statistical tendency $p<0.05$, it was shown that the direction of mass air inflow two weeks before pollination, had an influence on the APIn of birch pollen grains. The highest APIn was recorded in the case when the airflow from E + SEa was dominant or in the case of a central anti-cyclonic situation (high-pressure centre) and anti-cyclonic ridge or highpressure ridge $(\mathrm{Ca}+\mathrm{Ka})$ (Fig. 7). Synoptic conditions for 4 and 28 days prior to the start of the season 
Table 12 Results of a comparative analysis using the Kruskal-Wallis test for the birch pollen concentration in terms of the direction of mass air inflow

\begin{tabular}{lccc}
\hline \multicolumn{2}{c}{ APIn } & & Me $(Q 1-Q 3)$ \\
\cline { 2 - 4 } & $M$ & 504.55 & $1.907 .92(1.513 .4-1.907 .92)$ \\
\hline $\mathrm{N}+\mathrm{NEa}$ & 1.978 .77 & 10.347 .93 & $8.872 .5(4.581 .5-24.714 .25)$ \\
$\mathrm{E}+\mathrm{SEa}$ & 11.226 .80 & 1.339 .97 & $1.152 .5(205-1.152 .5)$ \\
$\mathrm{W}+\mathrm{NWa}$ & 1.152 .50 & 5.297 .88 & $6.292 .5(1.526 .75-11.100 .19)$ \\
$\mathrm{Ca}+\mathrm{Ka}$ & 6.306 .48 & 4.981 .60 & $18.380 .5(12.709-22.040 .5)$ \\
$\mathrm{W}+\mathrm{NWc}$ & 17.710 .00 & 8.534 .98 & $10.879(5.792-21.073 .5)$ \\
$\mathrm{Cc}+\mathrm{Bc}$ & 12.581 .50 & & \\
$p$ & $\mathrm{p}<0.05$ & &
\end{tabular}

$M$, Average; $S D$, Standard deviation; $Q 1$, First quartile; $M e$ - median; $Q 3$, Third quartile

Anti-cyclonic situations: $\mathrm{N}+\mathrm{NEa}, \mathrm{E}+\mathrm{Sea}, \mathrm{S}+\mathrm{Swa}, \mathrm{W}+\mathrm{NWa}, \mathrm{Ca}+\mathrm{Ka}, \mathrm{Ca}-$ central anticyclone situation (high centre), Kaanti-cyclonic wedge or ridge of high pressure

Cyclonic situations: $\mathrm{N}+\mathrm{NEc}, \mathrm{E}+\mathrm{Sec}, \mathrm{S}+\mathrm{SWc}, \mathrm{W}+\mathrm{NWc}, \mathrm{Cc}+\mathrm{Bc}, \mathrm{Cc}-$ central cyclonic, centre of low, Bc-the trough of low pressure (different directions of airflow and frontal system in the trough axis)

$\mathrm{x}$ undefined type

The letters: N, NE, E, SE, S, W, NW, SW indicate the directions of air mass inflow

were also checked, but the results were statistically insignificant.

Comparative analyses using the Kruskal-Wallis tests were also conducted for the sum of birch pollen grains and the duration of the season due to the type of air mass occurring 4, 14, and 28 days before pollination. The results of the analyses turned out statistically insignificant, $p>0.05$, which means that the type of air mass occurring before the birch pollination did not influence the concentration level of pollen grains or the duration of pollen seasons.

\subsection{The cluster analysis}

The following analysis aimed to verify whether among the pollen seasons in the years 1997-2020 there are any similarities in terms of daily concentration of pollen grains, APIn, and the duration of pollen seasons. With the help of a cluster analysis conducted
Fig. 7 The median sum of birch pollen grains broken down by the direction of mass air inflow within two weeks before the start of the pollen season

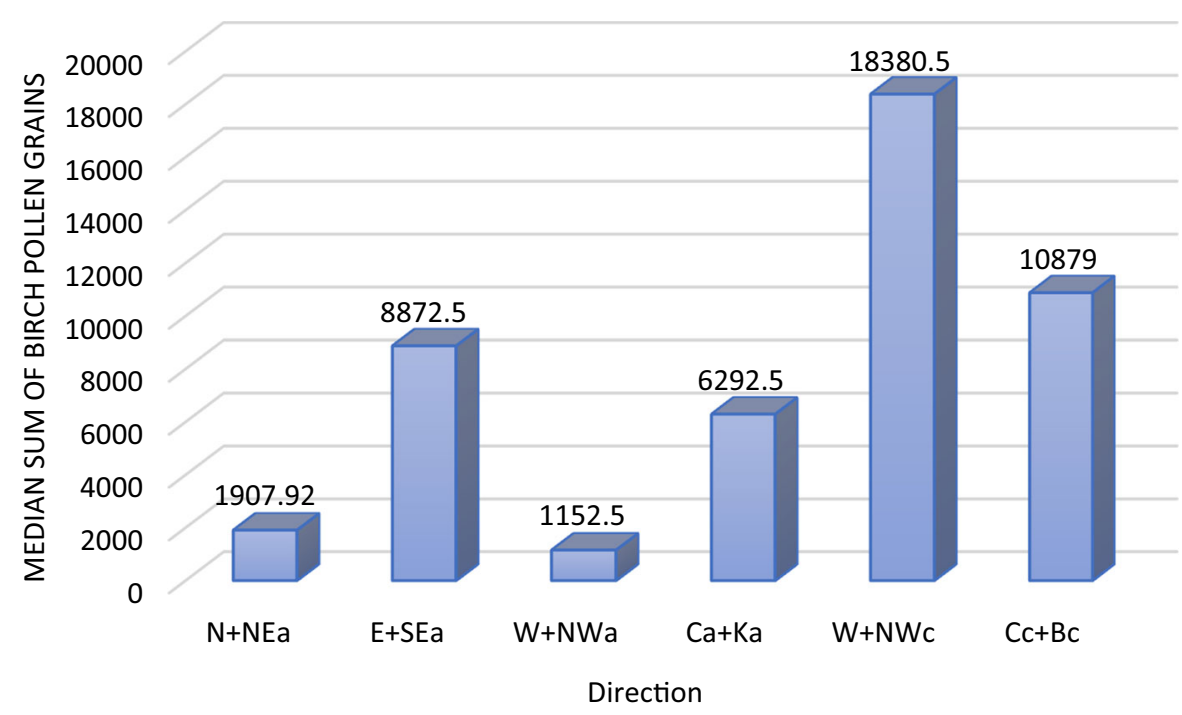


using the k-means method, it was verified whether and how pollen seasons correlate (Table 13 ).

The cluster analysis divided pollen seasons into 3 clusters. The first cluster takes in the initial years of 1997-1999, and since 2005 every second pollination period is examined. Cluster II covered the years 2000-2001, and then 2004, 2010, 2012, 2014, and 2018-2020. Cluster III covered 2003, 2006, 2008, and 2016. The clusters were compared to specify whether they differ statistically significantly in terms of weather. For this purpose, a series of analyses were conducted with Kruskal-Wallis tests, the results of which are presented in Supplementary Material section (Table SM-1).The analyses conducted using the Kruskal-Wallis tests showed that the clusters I-II-III differed from each other to a statistically significant degree in terms of the average and total birch pollen concentration $p<0.001$. The highest birch pollen concentration was recorded in cluster III, that is, in the years 2003, 2006, 2008, and 2016. The lowest, meanwhile, was recorded in cluster I. It is worth noting that cluster I covered periods occurring, more or less, every two years. This means that the years with high APIn were interspersed with years of low APIn. However, no differences were demonstrated between the clusters regarding the amount of pollen, duration of seasons and weather.

Table 13 Results of cluster analyses using the k-means method for the division of birch pollen seasons

\begin{tabular}{lll}
\hline Cluster I & Cluster II & Cluster III \\
\hline 1997 & 2000 & 2003 \\
1998 & 2001 & 2006 \\
1999 & 2004 & 2008 \\
2002 & 2010 & 2016 \\
2005 & 2012 & \\
2007 & 2014 & \\
2009 & 2018 & \\
2011 & 2019 & \\
2013 & & \\
2015 & & \\
2017 & & \\
2020 & & \\
\hline
\end{tabular}

\section{Discussion}

Pollen seasons of early spring trees and bushes are characterized by high variability in particular years, both in terms of their duration and degree of pollen concentration (Spieksma et al., 2003). The periods of plant pollination, particularly in early-spring plants, are strictly dependent on weather conditions, and it is in this group of plants where the highest pollen season dynamics are visible.

This includes birch, in the case of which the start date of the pollen season can vary even up to a month, as happened in 1999 and 2013. The analyses conducted showed that the birch pollen season starts earlier, if 14 days before the beginning of the season, the average air temperature and the amount of sunlight are high. This phenomenon can be explained by the anthers opening only after absorbing a specific dose of thermal energy. However, a later start of the pollen season was observed when before the beginning of the pollen season there was high precipitation and high wind speeds. This dependency also confirms the earlier research where it was determined that a high frequency of days with precipitation, as well as a drop in temperature, might lead to a substantial shift of the pollination process, and even to its limitation (Chuine et al., 1998; Jato et al., 2007; Newnham et al., 2013). Sofiev et al. (2013) demonstrated that strong wind stimulates pollen release, but only to a specific threshold value. If the wind speed exceeds $5 \mathrm{~m} / \mathrm{s}$, it does not affect the tempo of the pollen release since it is limited by the pollen grain concentration in the catkins prepared for release.

Menut et al. (2014) concluded that the temperature, precipitation, and relative humidity are significantly correlated with the pollen concentrations measured. Analyses conducted for birch pollen seasons in Sosnowiec also proved that the weather conditions indicated above greatly influence daily concentrations of birch pollen. In addition, there were significant positive correlations found for average and maximum wind speed. Stronger wind increases the emission rate of pollen grains and improves ventilation and promotes turbulent mixing, which may explain the higher daily concentrations in stronger winds (and the positive correlation coefficient) (Sofiev et al., 2013). In addition, the distance over which pollen grains are carried depends mainly on the direction and strength of the wind. Many studies indicate that airborne pollen 
concentration in most taxa is positively, statistically significantly related to maximum wind speed (Puc \& Kasprzyk, 2013; Puc \& Wolski, 2002).

Previous studies conducted in Sosnowiec for other tree taxa indicated similar correlations (DąbrowskaZapart \& Niedźwiedź, 2020; Dąbrowska-Zapart et al., 2018). The significant correlations between weather conditions and the birch pollen concentration have been observed by other researchers as well (Grewling et al., 2012; Nowosad et al. 2015; Puc et al., 2015; Tseng et al., 2018; Kubik-Komar et al., 2019; Sauliene et al., 2019).

The impact of precipitation on the airborne pollen concentration is significant but not explicitly specified. Many aerobiological studies indicate a crucial influence of precipitation on daily pollen concentration due to the leaching effect (Rojo et al., 2015). Grewling et al. (2012) concluded that precipitation in a birch pollen season significantly influenced the decrease in daily concentrations, but only for a season of low intensity. The influence of temperature on the birch pollen concentration seems more significant than the influence of precipitation. Spring precipitation may be convective and related to increased pollen concentration in the first two hours of precipitation (Norris-Hill \& Emberlin, 1993). In Sosnowiec, the relation between precipitation and the daily concentration of birch pollen grains turned out to be statistically significant. For this correlation, a negative correlation factor was obtained, which means that precipitation lowers the concentration levels of airborne birch pollen. According to Hyde (1950), precipitation acts on pollen concentration in two ways. It reduces the release of pollen by plants, as most plants do not open anthers in moist air, and it removes all aeroplankton from the air, especially if it is prolonged precipitation.

In birch, male flowers begin to form in May until the end of June in the year preceding flowering (Caesar $\&$ Macdonald, 1983, 1984). Since pollen dispersion in a given year is correlated with the number of male flowers which developed in the summer of the preceding year, the total number of pollen is strictly related to the meteorological variables of the previous summer (Ranta et al., 2008; Yasaka et al., 2009). Among them, temperature and duration of sunlight are considered the most important (Matthews, 1955; Norton \& Kelly, 1988), as they influence the assimilation capacity when producing carbohydrates during the formation of a male flower (Dahl \& Strandhede,
1996). Significant correlations with meteorological conditions prevailing in the year preceding pollination were found in Sosnowiec as well. The relative air humidity mostly influenced the APIn of birch in Sosnowiec in the period of July-September in the preceding year (positive correlation). Statistically significant factors were also obtained for the maximum temperature, sunlight duration, and average and maximum wind speed in the period specified above. For relative humidity, average temperature and duration of sunlight, positive correlation coefficients were obtained; that is, high values of these meteorological elements contribute to the production of a high amount of birch pollen in the following season. However, for average and maximum wind speed, negative correlation coefficients were found. Sometimes wind causes mechanical damage to anthers and increases transpiration and evaporation of soil water, which can probably indirectly affect the formation of male birch flowers. This could explain the negative correlation coefficient.

The variation of the birch pollen grain concentration and of weather conditions during pollination over the years was also examined. Using Spearman's rho correlation analysis, it has been shown that the birch pollen grain concentration was increasing yearly.

The correlation between pollen concentrations and weather fronts was demonstrated by Goyette-Pernot et al. (2003) as well as Nowosad et al. (2015). Nowosad et al. (2015) showed, on the one hand, a strong correlation between the transient variability of the pollen concentration of alder, hazel, and birch in Poland, and on the other, the exchange of air masses. They suggested that from 30 to $40 \%$ of the variability in the pollen concentration is correlated with a single weather front passage. Goyette-Pernot et al. (2003) concluded that the movement of fronts often increases the presence of Ambrosia pollen climaxes of regional scale in Montreal. They also demonstrated that anticyclonic conditions contribute to the local production of pollen but hinder its spreading on a larger scale. Also, according to Laaidi (2001), the pollen grain concentration may be influenced by the type of atmospheric circulation (cyclonic or anti-cyclonic). According to the author, higher pollen grain concentrations occur in the case of anti-cyclonic situations. Grundström et al. (2017) concluded that the approach based on types of weather is a relatively easy method for characterizing weather conditions on a synoptic 
scale; it groups many meteorological variables relevant to the processes deciding on high or low concentration levels of pollen. Studies conducted in Göteborg and Malmö showed that high concentrations of birch pollen were correlated with dry and moderately calm conditions during an anti-cyclone and types of weather with geostrophic NE, SE, and S winds, and the lowest concentration levels were found in humid and windy conditions with wind directions SW, W, and NW, as well as for a cyclonic type (Grundström et al., 2017). Ojrzyńska et al. (2020) noted that the highest pollen concentration for both alder and birch in Wrocław (Poland) is observed during warm, sunny, and dry anti-cyclonic circulations an anti-cyclone in the lower and upper troposphere, especially for the types with advection from the SW direction. The lowest pollen concentrations are observed for cold, humid, and cloudy cyclonic circulation with advection from northern sectors. However, the number of studies where types of weather have been applied for pollen analysis is quite limited, particularly regarding Central Europe.

The analyses conducted in Sosnowiec showed that the highest daily birch concentrations were recorded when there was a stationary weather front or a situation without front, and the lowest daily concentrations were observed during an occluded front. Based on the median value and the interquartile range, it can be concluded that the highest concentration of birch pollen was recorded in the case of an mass air inflow from $\mathrm{E}+\mathrm{SEc}$ (eastern and south-eastern cyclonic flow) and E + SEa (eastern and southeastern anti-cyclonic flow), in the case of which warm and bright days were dominant. The lowest birch pollen concentration was recorded in the case of air inflow from $\mathrm{N}+\mathrm{NEc}$ (northern and north-eastern cyclonic flow), $\mathrm{N}+\mathrm{NEa}$ (northern and north-eastern anti-cyclonic flow), and $\mathrm{W}+\mathrm{NWa}$ (western and north-western anti-cyclonic flow) when there was usually cloudy and cold weather. Low concentrations also occurred when there was a central anti-cyclonic situation (high-pressure centre) and anti-cyclonic ridge or high-pressure ridge $(\mathrm{Ca}+\mathrm{Ka})$, as well as central cyclonic situation (low-pressure centre) or low-pressure furrow $(\mathrm{Cc}+\mathrm{Bc})$. Therefore, it cannot be unambiguously concluded which type of atmospheric circulation-cyclonic or anti-cyclonic-has a higher birch pollen concentration. Regarding the influence of air mass on the APIn of birch pollen concentration, it was concluded that the highest APIn was recorded when warm tropical air (T) and warm maritime polar air (wmP) mass was prevailing in the pollen season. The lowest APIn was correlated with cold, fresh maritime polar air, usually inflowing after a cold front (fmP) and Arctic front (A).

The length of birch pollen seasons was positively correlated with the relative air humidity during the season but negatively with the average and maximum wind speed. The higher the relative humidity, the longer the pollen season lasts. High wind speed, however, shortens the birch pollen season. According to Jabłoński and Szklanowska (1997), the pollination process occurs most intensely at low relative humidity and high air temperature. In warm sunny weather, the pollination period is short, and its course is very regular. In Sosnowiec, no statistically significant correlations between the air temperature and the duration of birch pollen seasons were found. On the other hand, weather conditions prevailing 14 days before the start of a pollen season influenced its duration. There were statistically significant negative coefficients of correlation between the length of the season and the maximum temperature, near-ground temperature, average temperature, and sunlight duration and wind speed occurring 14 days before the season. The season's length was additionally correlated with relative air humidity. It was also concluded that the duration of the birch pollen season was decreasing yearly.

However, no significant correlations were found between the duration of birch pollen seasons, the directions of air inflow, and the types of air mass and weather fronts.

The number of days with pollen grain concentration threshold values causing allergy symptoms varied during the 24 years of observation from 1 day in 1997 to 39 days in 2016. In 2008 and 2016, even though it was not a season exceptionally abundant in birch pollen, the highest number of days with threshold concentrations causing the first symptoms of allergy was observed $\left(\geq 20\right.$ grains $\left./ \mathrm{m}^{3}\right)$, with concentration values causing disease manifestations in all people hypersensitive to birch pollen allergens ( $\geq 75$ grains/ $\mathrm{m}^{3}$ ), and with concentration values causing symptoms of dyspnoea ( $\geq 155$ grains $/ \mathrm{m}^{3}$ ) (Rapiejko et al., 2007). Many days with threshold concentration values were also observed in 2000, 2004, 2006, 2008, 2013, and 2019. 
The purpose of the last study was to verify using k-means cluster analysis whether similarities exist between birch pollen seasons. Analyses with the method mentioned above were already conducted for oak in Sosnowiec (Dạbrowska-Zapart, 2010) and grass in Wrocław (Malkiewicz and Klaczka 2011). In the birch case, the cluster analysis divided pollen seasons into 3 clusters with statistically significant variation in the average and total amount of birch pollen. The first cluster took in the initial years of 1997-1999, and since 2005 it was every second pollination period examined. Cluster II covered 2000-2001, and then 2004, 2010, 2012, 2014, and 2018-2020. Cluster III covered 2003, 2006, 2008, and 2016. The highest birch pollen concentration was recorded in cluster III, that is, in 2003, 2006, 2008, and 2016. The lowest, however, was recorded in cluster I. It is worth noting that cluster I covered periods occurring, more or less, every two years. This means that the years with high APIn were interspersed with years of low APIn. This may be explained by the fact that in the case of some tree species, there may be an alternation in their flowering abundance, the so-called endogenous cycle, which to a large extent is independent of weather conditions (Hallsdóttir, 1999; Latorre, 1999; Detandt and Nolard 2000; Jato et al., 2002; Lamontagne \& Boutin, 2007). This is manifested in the fact that years with high pollen production occur alternately with low production years.

In Reykjavik (Iceland) (Hallsdóttir, 1999) and in Brussels (Belgium) (Detandt and Nolard 2000) a three-year cycle was observed in the case of birch, which means that a year with high annual values is separated by two years with low values of the APIn. In London (United Kingdom) (Emberlin et al., 1990), in Mar del Plata (Argentina) (Latorre, 1999), in Copenhagen (Denmark) (Rasmussen, 2002), in Gdansk (Poland) (Latałowa et al., 2002), and in Santiago de Compostela (Spain) (Jato et al., 2002) a two-year cycle was observed in the case of birch.

\section{Conclusions}

The start of the birch pollen season was accelerated by high mean temperature and sunshine 14 days before the season (negative correlation). On the other hand, high wind speed and high precipitation 14 days before the season delayed the start of the birch pollen season (positive correlation). The value of daily birch pollen concentration showed a statistically significant positive correlation between the sunlight duration and the average and maximum wind speed. However, a negative correlation was found for the minimum and near-ground temperature, relative humidity and precipitation.

The highest birch pollen concentration is observed in the case of an inflow of warmer air from the $\mathrm{E}+\mathrm{SEc}$ direction (eastern and south-eastern cyclonic), and $E+$ SEa direction (eastern and south-eastern anti-cyclonic). The lowest birch pollen concentration was recorded in the case of a colder air inflow from the $\mathrm{N}+\mathrm{NEc}$ direction (northern and north-eastern cyclonic flow), $\mathrm{N}+\mathrm{NEa}$ direction (northern and northeastern anti-cyclonic flow), and $\mathrm{W}+\mathrm{NWa}$ direction (western and north-western anti-cyclonic flow Warm maritime polar air was the air mass that exceptionally promoted high daily hazel concentrations.

High birch pollen concentrations were recorded in the case of a tropical air mass (T) and warm maritime polar air (wmP), whereas the lowest-in the case of old maritime polar air (omP) and Arctic air (A).

The APIn were influenced by the weather conditions in the season and those from the summer preceding the season. Statistically significant positive correlation coefficients were obtained for maximum temperature, sunshine, and relative humidity from July-September of the preceding year. On the other hand, statistically significant negative correlation coefficients were found for the maximum and mean wind speed for the period mentioned above.

The annual totals of birch pollen were found to depend on the ground temperature from 14 days before the start of the season. A statistically significant positive correlation was obtained for this meteorological element. In Sosnowiec, the length of the birch pollen seasons was affected by the maximum and mean wind speed (negative correlation coefficient) and relative air humidity (positive correlation coefficient) in the season. It also turned out that weather conditions influenced the length of birch pollen seasons from 14 days before the season. The seasons were shorter when the maximum, ground, and mean temperatures, sunshine, and wind speed from 14 days before the season were high. On the other hand, longer pollen seasons were observed in Sosnowiec when relative humidity from 14 days before the season was high. The highest number of days with threshold 
concentrations causing the first allergic symptoms, i.e. 20 grains $/ \mathrm{m}^{3}$ was recorded in the years $1997-1999$. However, the highest number of days with a concentration causing disease symptoms in all people hypersensitive to birch pollen allergens, that is $\geq 75$ grains/ $\mathrm{m}^{3}$ and with concentrations causing dyspnoea symptoms ( $\geq 155$ grains $/ \mathrm{m}^{3}$ ) was recorded in 2000, 2004, 2006, 2008, 2013, 2016, and 2019.

The cluster analysis with k-means method allowed for dividing the birch pollen seasons into 3 types varying in terms of pollen grain concentrations and the duration of seasons. The highest birch pollen concentration was recorded in cluster III, that is, in the years 2003, 2006, 2008, and 2016.

Open Access This article is licensed under a Creative Commons Attribution 4.0 International License, which permits use, sharing, adaptation, distribution and reproduction in any medium or format, as long as you give appropriate credit to the original author(s) and the source, provide a link to the Creative Commons licence, and indicate if changes were made. The images or other third party material in this article are included in the article's Creative Commons licence, unless indicated otherwise in a credit line to the material. If material is not included in the article's Creative Commons licence and your intended use is not permitted by statutory regulation or exceeds the permitted use, you will need to obtain permission directly from the copyright holder. To view a copy of this licence, visit http://creativecommons.org/licenses/by/4.0/.

\section{References}

Caesar, J. C., \& Macdonald, A. D. (1983). Shoot development in Betula papyrifera: II. Comparison of vegetative and reproductive short-shoot growth. Canadian Journal of Botany, 61, 3066-3071.

Caesar, J. C., \& Macdonald, A. D. (1984). Shoot development in Betula papyrifera. IV. Comparisons between growth characteristics and expression of vegetative long and short shoots. Canadian Journal of Botany, 62, 446-453.

Chuine, I., Cour, P., \& Rousseau, D. (1998). Fitting models predicting dates of flowering of temperate-zone trees using simulated annealing. Plant Cell and Environment, 21, 455-466.

D‘Amato, D., Cecchi, L., Bonini, S., Nunes, C., Annesi-Maesano, I., Behrendt, H., Liccardi, G., Popov, T., van Cauwenberge, P. (2007). Allergenic pollen and pollen allergy in Europe. Allergy, 62(9), 976-990.

Dąbrowska-Zapart, K. (2010). Sezony pyłkowe dębu w Sosnowcu w latach 1997-2007 (Oak pollen season in Sosnowiec in 1997-2007). Alergoprofil, 6(2), 38-45.

Dąbrowska-Zapart, K., \& Niedźwiedź, T. (2020). The impact of weather conditions on hazel pollen concentration in Sosnowiec (Poland) in 1997-2019. Aerobiologia, 36, 697-713. https://doi.org/10.1007/s10453-020-09661-9
Dąbrowska-Zapart, K., Chłopek, K., \& Niedźwiedź, T. (2018). The impact of meteorological conditions on the concentration of alder pollen in Sosnowiec (Poland) in the years 1997-2017. Aerobiologia, 34(4), 469-485. https://doi.org/ 10.1007/s10453-020-09661-9

Dahl, A., \& Strandhede, S. O. (1996). Predicting the intensity of the birch pollen season. Aerobiologia, 12, 97-106.

Dalen, G., \& Voorhorst, R. (1981). Allergen community in pollen from certain tree species. Annals of Allergy, Asthma \&amp; Immunology, 46, 276-278.

Detandt, M., Nolard, N. (2000). The fluctuations of the allergenic pollen content of the air in Brussels (1982 to1997). Aerobiologia, 16, 55-61.

Dosio, A., \& Paruolo, P. (2011). Bias correction of the ENSEMBLES high-resolution climate change projections for use by impact models: Evaluation on the present climate. Journal of Geophysical Research: Atmospheres, 116, 16.

Ebner, C., Hirschwehr, R., Bauer, L., Breiteneder, H., Valenta, R., Ebner, H., \& Scheiner, O. (1995). Identification of allergens in fruits and vegetables: IgE cross-reactivities with the important birch pollen allergens Bet v 1 and Bet $\mathrm{v}$ 2 (birch profilin). Journal of Allergy and Clinical Immunology, 95(5), 962-969.

Emberlin, J., Norris-Hill, J., \& Bryant, R. H. (1990). A calendar for tree pollen in London. Grana, 29, 301-309. https://doi. org/10.1080/00173139009428941

Emberlin, J., Jones, S., Bailey, J., Caulton, E., Corden, J., Dubbels, S., Evans, J., Mc Donagh, N., Millington, W., Mullins, J., Russel, R., \& Spencer, T. (1994). Variation in the start of the grass pollen season at selected sites in the United Kingdom 1987-1992. Grana, 33, 94-99. https:// doi.org/10.1080/00173139409427839

Eriksson, N. E., Wih, J. A., Arrendal, H., \& Strandhede, S. O. (1987). Tree pollen allergy III. Allergy, 42, 205-214.

Goyette-Pernot, J., Muñoz-Alpizar, R., Blanchet, J. P., Goyette, S., Beniston, M. (2003). Analysing ragweed pollen cloud over Montreal city center. In Proceedings of the 5th International Conference on Urban Climate, Lodz.

Grewling, Ł, Jackowiak, B., Nowak, M., Uruska, A., \& Smith, M. (2012). Variations and trends of birch pollen seasons during 15 years (1996-2010) in relation to weather conditions in Poznań (western Poland). Grana, 51(4), 280-292.

Grundström, M., Dahl, Å., Ou, T., Chen, D., \& Pleijel, H. (2017). The relationship between birch pollen, air pollution and weather types and their effect on antihistamine purchase in two Swedish cities. Aerobiologia, 33, 457-471. https://doi.org/10.1007/s10453-017-9478-2

Hallsdóttir, M. (1999). Birch pollen abundance in Reykjavik, Iceland. Grana, 38, 368-373.

Hyde, H. A. (1950). Pollen incidence on Skomer. In: J. Buxton \& R. M. Lockley (Eds.), The Island of Skomer (pp. 45). London

Jabłoński, B., Szklanowska, K. (1997). Wpływ niektórych czynników pogody na kwitnienie, nektatowanie, pylenie i oblot przez owady zapylające entomofilnych roślin uprawnych, I Ogólnopolska Konferencja Naukowa Biologia kwitnienia, nektarowania i zapylania roślin Lublin, pp. 53-58. 
Jato, V., \& Rodriguez-Rajo, F. J., Aira, M. J. (2007). Use of phenological and pollen-production data for interpreting atmospheric birch pollen curves. Annals of Agricultural and Environmental Medicine, 14, 271-280.

Jato, V., Dopazo, A., \& Aira, M. J. (2002). Influence of precipitation and tempertaure on airborne pollen concentration in Santiago de Compostela (Spain). Grana, 41, 232-241.

Jędrzejko, K. (1993). Tereny zielone Sosnowca, charakterystyka florystyczno ekologiczna [Green areas of Sosnowiec, floristic and ecological characteristics]. In M. Wanatowicz (Ed.), Rocznik Sosnowiecki 1993 - tom 2 (pp. 116-139). Sosnowiec: Urząd Miejski w Sosnowcu.

Kubik-Komar, A., Piotrowska-Weryszko, K., Weryszko-Chmielewska, E., Kuna-Broniowska, I., Chłopek, K., Myszkowska, D., Puc, M., Rapiejko, P., Ziemianin, M., Dąbrowska-Zapart, K., \& Lipiec, A. (2019). A study on the spatial and temporal variability in airborne Betula pollen concentration in five cities in Poland using multivariate analyses. Science of the Total Environment, 660, 1070-1078. https://doi.org/10.1016/j.scitotenv.2019.01. 098

Laaidi, K. (2001). Predicting days of high allergenic risk during Betula pollination using weather types. International Journal of Biometeorology, 45, 124-132. https://doi.org/ 10.1007/s004840100096

Lamontagne, J. M., \& Boutin, S. (2007). Local-scale synchrony and variability in mast seed production patterns of Picea glauca. Journal of Ecology, 95, 991-1000. https://doi.org/ 10.1111/j.1365-2745.2007.01266.x

Latałowa, M., Mietus, M., \& Uruska, A. (2002). Seasonal variations in the atmospheric Betula pollen count in Gdańsk (southern Baltic coast) in relation to meteorological parameters. Aerobiologia, 18, 33-43.

Latorre, F. (1999). Differences between airborne pollen and flowering phenology of urban trees with reference to production, dispersal and interannual climate variability. Aerobiologia, 15, 131-141.

Lipiec, A., Rapiejko, P., Samolinski, B., \& Krzych, E. (2005). Correlation between conjunctival provocation test results and conjunctival symptoms in pollinosis - preliminary report. Annals of Agricultural and Environmental Medicine, 12(1), 17-20.

Malkiewicz, M., \& Klaczak, K. (2011). Analysis of the grass (Poaceae L.) pollen seasons in Wrocław, 2003-2010. Acta Agrobotanica, 64(4), 59-66.

Mandrioli, P., Comtois, P., Dominiguez-Vilches, E., Galan, C., Syzdek, L. D., \& Issard, S. A. (1998). Sampling: Principles and Techniques. In P. Mandrioli, P. Comtois, \& V. Levizzani (Eds.), Methods in Aerobiology (pp. 47-112). Pitagora Editrice Bologna.

Matthews, J. (1955). The influence of weather on the frequency of beech mast years in England. International Journal of Forestry Research, 28, 107-116.

Menut, L., Vautard, R., Colette, A., Khvorostyanov, D., Potier, A., Hamaoui-Laguel, L., Viovy, N., \& Thibaudon, M. (2014). A new model of ragweed pollen release based on the analysis of meteorological conditions. Atmospheric Chemistry and Physics, 14, 10891-10927. https://doi.org/ 10.5194/acpd-14-10891-2014
Mothes, N., \& Valenta, R. (2004). Biology of tree pollen allergens. Current Allergy and Asthma Reports, 4(5), 384-390.

Newnham, R. M., Sparks, T. H., Skjøth, C. A., Head, K., Adams-Groom, B., \& Smith, M. (2013). Pollen season and climate: Is the timing of birch pollen release in the UK approaching its limit? International Journal of Biometeorology, 57, 391-400.

Niedźwiedź, T., Małarzewski, Ł. (2016). Klimat Sosnowca. In: A. Barciak, A. T. Jankowski (Eds.) Sosnowiec. Obraz miasta i jego dzieje (74-86). Sosnowiec: Muzeum w Sosnowcu.

Niedźwiedź, T. (1981). Sytuacje synoptyczne i ich wpływ na zróżnicowanie wybranych elementów klimatu w dorzeczu górnej Wisły. Rozprawy Habilitacyjne nr 58. Kraków: Uniwersytet Jagielloński (Synoptic situations and their influence on spatial differentiation of chosen elements of climate of the upper Vistula a Basin).

Niedźwiedź, T. (2004). Kalendarz sytuacji synoptycznych dla dorzecza górnej Wisły (1997-2004); plik komputerowy dostępny w Katedrze Klimatologii, Wydział Nauk o Ziemi Uniwersytetu Śląskiego, Sosnowiec (Calendar of synoptic situations for Upper Wisła Basin; computer packet available in Climatology Department, Earth Science Faculty, Silesian University).

Niedźwiedź, T. (2006). Typologia cyrkulacji atmosfery dla Polski i metody określania regionalnych wskaźników cyrkulacji. Annales Universitatis Mariae CurieSktodowska Sectio b: Geographia, Geologia, Mineralogia Et Petrographia, 61(38), 326-335.

Norris-Hill, J., \& Emberlin, J. (1993). The incidence of increased pollen concentrations during rainfall in the air of London. Aerobiologia, 9(1), 27-32.

Norton, D., \& Kelly, D. (1988). Mast seeding over 33 years by Dacrydium cupressinum Lamb. (rimu) (Podocarpaceae) in New Zealand: The importance of economies of scale. Functional Ecology, 2, 399-408.

Nowosad, J. (2015). Spatiotemporal models for predicting high pollen concentration level of Corylus, Alnus, and Betula. International Journal of Biometeorology, 60, 843-855. https://doi.org/10.1007/s00484-015-1077-8

Ojrzyńska, H., Bilińska, D., Werner, M., Kryza, M., \& Malkiewicz, M. (2020). The influence of atmospheric circulation conditions on Betula and Alnus pollen concentrations in Wrocław, Poland. Aerobiologia, 36, 261-276. https://doi.org/10.1007/s10453-020-09629-9

Puc, M., Wolski, T., Camacho, I. C., Myszkowska, D., Kasprzyk, I., Grewling, Ł, Nowak, M., Weryszko-Chmielewska, E., Piotrowska-Weryszko, K., Chłopek, K., DąbrowskaZapart, K., Majkowska-Wojciechowska, B., Balwierz, Z., Malkiewicz, M., Grinn-Gofron, A., Stacewicz, A., Kruczek, A., \& Borycka, K. (2015). Fluctuation of birch (Betula L) pollen seasons in Poland. Acta Agrobotanica, 68(4), 303-313.

Puc, M., \& Kasprzyk, I. (2013). The patterns of Corylus and Alnus pollen seasons and pollination periods in two Polish cities located in different climatic regions. Aerobiologia, 29, 495-511.

Puc, M., \& Wolski, T. (2002). Betula and Populus pollen counts and meteorological conditions in Szczecin, Poland. Annals of Agricultural and Environmental Medicine, 9, 65-69. 
Ranta, H., Hokkanen, T., Linkosalo, T., Laukkanen, L., Bondestam, K., \& Oksanen, A. (2008). Male flowering of birch Spatial synchronization, year-to-year variation and relation of catkin numbers and airborne pollen counts. Forest Ecology Management, 255, 643-650.

Rapiejko, P., Wojdas, A., Kantor, I., Zielnik-Jurkiewicz, B., \& Lipiec, A. (2003). Progowe stężenie pyłku traw niezbędne do wywołania objawów uczuleniowych. Alergía, 2, 60-62.

Rapiejko, P., Puc, M., Lipiec, A., Myszkowska, D., Malkiewicz, M., Chłopek, K., Antonik, P., Wojdas, A., \& Stankiewicz, W. (2006). Analiza stężenia pyłku brzozy w wybranych miastach Polski w 2006 roku. Alergoprofil, 2(2), 43-51.

Rapiejko, P., Stankiewicz, W., Szczygielski, K., \& Jurkiewicz, D. (2007). Threshold pollen count necessary to evoke allergic symptoms. Otolaryngologia Polska, 61(4), 591-594.

Rasmussen, A. (2002). The effects of climate change on the birch pollen season in Denmark. Aerobiologia, 18, 253-265.

Rojo, J., Rapp, A., Lara, B., Fernández-González, F., \& PérezBadia, R. (2015). Effect of land uses and wind direction on the contribution of local sources to airborne pollen. Science of the Total Environment, 538, 672-682.

Samoliński, B., Raciborski, F., Lipiec, A., Tomaszewska, A., Krzych-Fałta, E., Samel-Kowalik, P., Walkiewicz, A., Lusawa, A., Borowicz, J., Komorowski, J., SamolińskaZawisza, U., Sybilski, A. J., Piekarska, B., \& Nowicka, A. (2014). Epidemiologia Chorób Alergicznych w Polsce (ECAP) (Epidemiology of allergic diseases in Poland). Polish Journal of Allergology, 1(1), 10-18. https://doi.org/ 10.1016/j.alergo.2014.03.008

Sauliene, I., Sukiene, L., \& Kazlauskiene, V. (2019). The assessment of atmospheric conditions and constituents on allergenic pollen loads in Lithuania. Journal of Environmental Management, 15(250), 109469. https://doi.org/10. 1016/j.jenvman.2019.109469

Skjøth, C. A., Geels, C., Hvidberg, M., Hertel, O., Brandt, J., Frohn, L. M., Hansen, K. M., Hedegaard, G. B., Christensen, J. H., \& Moseholm, L. (2008). An inventory of tree species in Europe-an essential data input for air pollution modelling. Ecological Modelling, 217(3), 292-304.

Skjøth, C. A., Werner, M., Kryza, M., Adams-Groom, B., Wakeham, A., Lewis, M., \& Kennedy, R. (2015). Quality of the governing temperature variables in WRF in relation to simulation of primary biological aerosols. Advances in Meteorology. https://doi.org/10.1155/2015/412658

Skjøth, C. A., Šikoparija, B., Jäger, S., and EAN-Network (2013). Pollen Sources. In: M. Sofiev, Bergmann K. C. (Ed.), Allergenic Pollen: A Review of the Production, Release, Distribution and Health Impacts. Springer Dordrecht, Heidelberg, New York, London, [pp 9-27].

Sofiev, M., Siljamo, P., Ranta, H., \& Linkosalo, T. (2013). A numerical model of birch pollen emission and dispersion in the atmosphere Description of the emission module. International Journal of Biometeorology, 57, 45-58.

Spieksma, FTh., \& M., Nikkels, A. H. (1998). Airborne grass pollen in Leiden, The Netherlands: Annual variations and trends in quantities and season starts over 26 years. Aerobiologia, 14, 347-358.

Spieksma, F., Corden, J. M., Detandt, M., Millington, W. M., Nikkels, H., Nolard, N., Schoenmakers, C. H. H., Wachter, R., de Weger, L. A., Willems, R., \& Emberlin, J. (2003). Quantitative trends in annual totals of five common airborne pollen types (Betula, Quercus, Poaceae, Urtica and Artemisia), et five pollen-monitoring stations in western Europe. Aerobiologia, 19, 171-184.

Szweykowska, A., Szweykowski, J. (2003). Słownik botaniczny (botanical dictionary). Wiedza Powszechna, Warszawa.

Traidl-Hoffmann, C., Kasche, A., Menzel, A., Jakob, T., Thiel, M., Johannes, R., \& Behrendt, H. (2003). A Impact of pollen on human health: More than allergen carriers? International Archives of Allergy and Immunology, 131, 1-13. https://doi.org/10.1159/000070428

Tseng, Y. T., Kawashima, S., Kobayashi, S., Takeuchi, S., \& Nakamura, K. (2018). Algorithm for forecasting the total amount of airborne birch pollen from meteorological conditions of previous years. Agricultural and Forest Meteorology, 249, 35-43. https://doi.org/10.1016/j. agrformet.2017.11.021

Veriankaite, L., Siljamo, P., Sofiev, M., Sauliene, I., \& Kukkonen, J. (2010). Modelling analysis of source regions of long-range transported birch pollen that influences allergenic seasons in Lithuania. Aerobiologia, 26, 47-62. https://doi.org/10.1007/s10453-009-9142-6

Yasaka, M., Kobayashi, S., Takeuchi, S., Tokuda, S., Takiya, M., \& Ohno, Y. (2009). Prediction of birch airborne pollen counts by examining male catkin numbers in Hokkaido, northern Japan. Aerobiologia, 25, 111-117. https://doi.org/ 10.1007/s10453-009-9116-8 